\title{
FARMING SYSTEMS AND CROP DIVERSITY IN SELECTED PROTECTED AREAS IN THE VISAYAS
}

\author{
Teofanes A. Patindol \\ Visayas State University, Visca, Baybay, Leyte
}

\begin{abstract}
Agricultural production systems inside protected areas are shifting from subsistence to cash economy. Along this shift, farming systems are also significantly changing from low to high intensity cropping, characterized by continuous cultivation and heavy application of inorganic fertilizer and pesticides. Based on the main crops grown, spatial arrangement and cropping intensities, the different crop production systems were identified such as traditional mosaic, low-input mosaic, low-input abaca-based intercrop, low input staples, and high input vegetables.
\end{abstract}

Crop diversity at the farm level is generally low. Perennial crops are integrated into the farming system but are limited to few species of fruit crops and exotic forest trees. Farm level species diversity is positively related to age, number of years in farming, household size, farm size, off-farm income, and number of years with livelihood projects. Livelihood module must be implemented and institutional support be strengthened to lessen dependence of inhabitants of protected areas on these less sustainable production systems.

KEY WORDS: Protected areas. Farming systems. Crop diversity 


\section{INTRODUCTION}

The Convention on Biological Diversity, one of the offshoots of the 1992 Rio Earth Summit, emphasizes the crucial role to be played by protected areas around the world in the conservation of biodiversity (Glowka et al, 1994). The first two lines of Article 8 of the convention (in-situ conservation) state:

Each contracting party shall, as far as possible and as appropriate:

a) Establish a system of protected areas or areas where special measures need to be taken to conserve biological diversity; and

b) Develop, where necessary, guidelines for the selection, establishment and management of the protected areas or areas where special measures need to be taken to conserve biological diversity.

Furthermore, the convention also recognizes the close and traditional dependence of many indigenous and local communities embodying traditional lifestyles on biological resources, and the desirability of sharing equitably benefits arising from the use of traditional knowledge, innovations and practices relevant to the conservation of biological diversity and the sustainable use of its components.

The most visible innovation in the contemporary protected areas system in the country today is to allow local communities (indigenous or tenured migrants) to utilize resources inside protected areas, particularly in areas designated as multiple-use management zones (DENR, 1992). Resource use in most protected areas is of typical agricultural subsistence economy, supplemented by gathering plants, and occasionally animal and fish products (De Boer and Baquete, 1998). Agricultural productivity in many protected areas is low, which is one of the primary reasons in the importance of natural resources available in protected areas. Natural resources significantly contributed to the different subsistence needs of the rural people. 
Since there has been a generalization that migrants usually pursue resource-use patterns that are destructive and thereby, becoming a serious threat to biodiversity, the study investigated the expected changes in their production systems under the present set-up of the NIPAS system. Moreover, the study provided practical bases in formulating and implementing sitespecific future strategies with due consideration on the production systems to address socio-economic and cultural dimensions in managing the protected areas for sustainable development.

\section{METHODOLOGY}

Respondents of the study were selected from three protected areas in Bohol and Leyte. The protected areas include the Rajah Sicatuna Protected Landscape (RSPL) in Bohol, Lake Danao Natural Park (LDNP), and Philippine National Oil Company (PNOC) Geothermal Reservation in Leyte. Eight villages were identified for the study. Six villages of which were situated inside protected areas while two were situated outside protected areas. Of the six villages situated inside protected areas, five were in Leyte and one was in Bohol. For the villages outside protected areas, one area was located in Leyte and in Bohol. The 8 study villages were distributed in Ormoc City and Albuera in Leyte and in Batuan and Carmen in Bohol (Figures 1 and 2). At least fifty percent of the households in each village were randomly selected to serve as respondents. A total of 147 household heads were interviewed from the study villages. The distribution of respondents is shown in Table 1.

The PNOC Geothermal Reservation covers an area of 107,625 hectares in the central cordilleras of Leyte Island. With the primary purpose of geothermal exploration and utilization, the reservation was declared through proclamation No. 1412 in April 1975. The reservation has important bearing upon the conservation of biodiversity because it contains vast areas of the last remaining forest in Leyte Island, which is recognized recently as one of the biodiversity areas in the country that requires urgent protection (Heywood and Watson, 1995). 


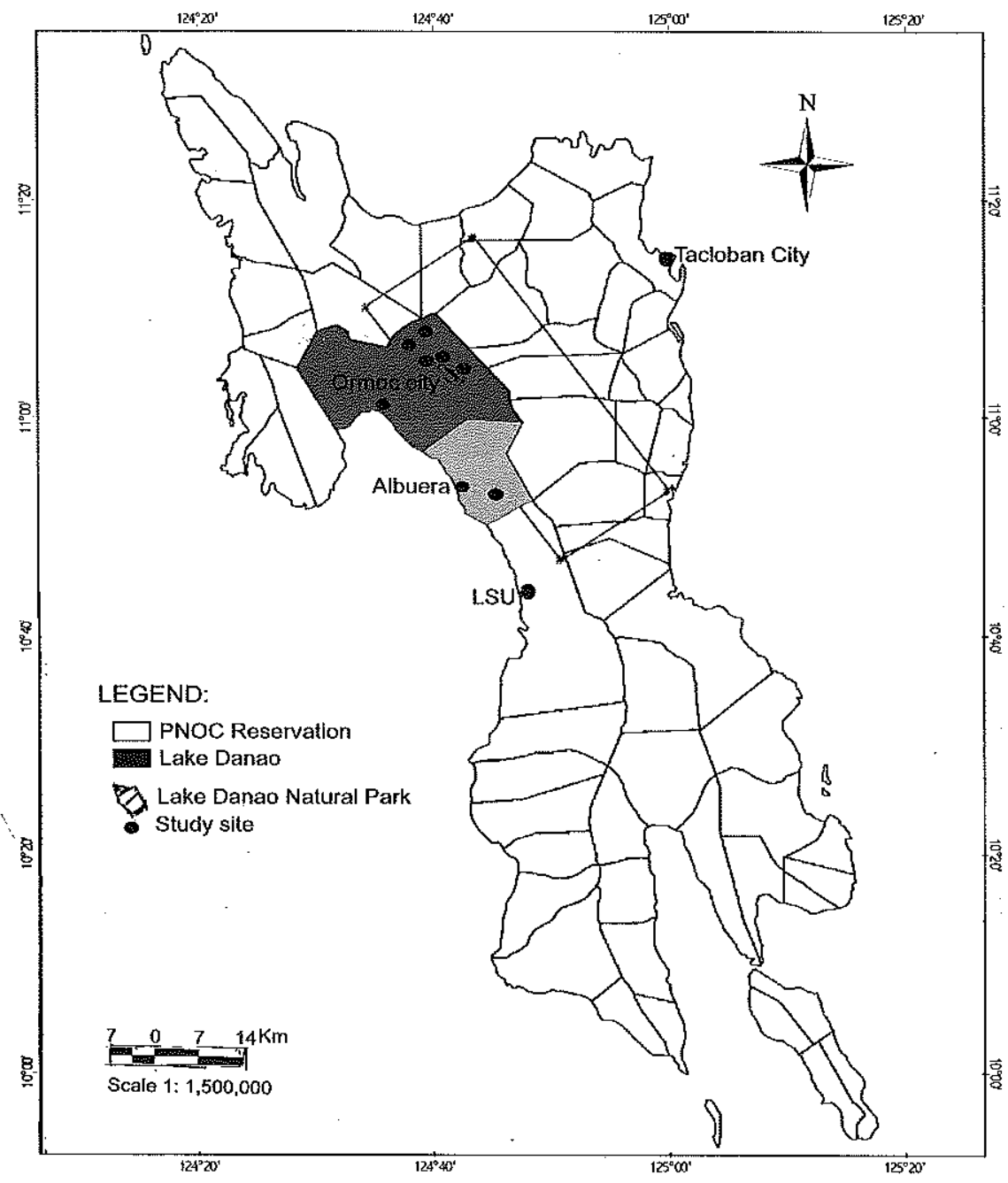

Figure1. Map of Leyte showing the location of the study sites. 


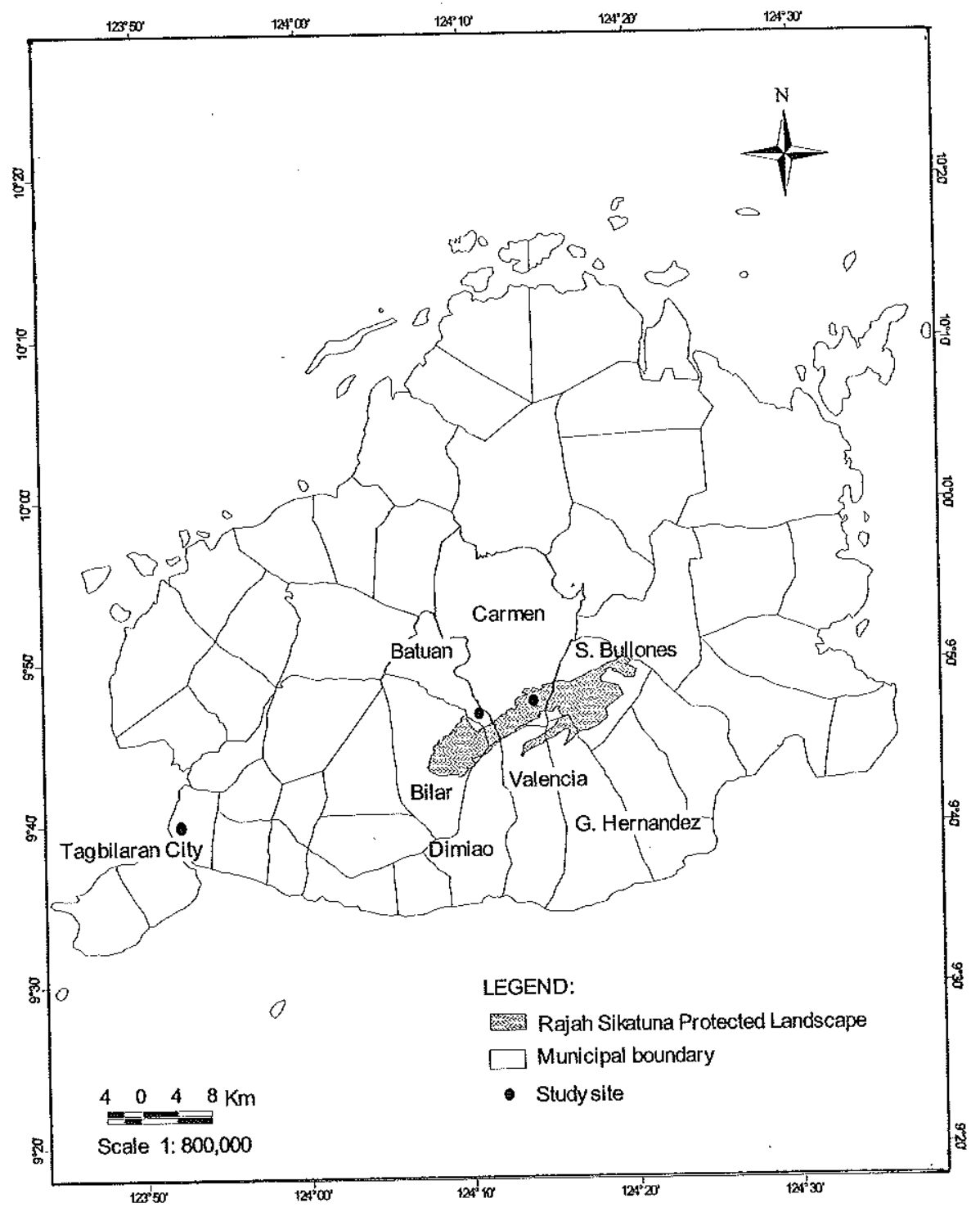

Figure 2. Map of Bohol showing the location of the study sites. 
Table 1. Distribution of respondents by study village in three protected areas.

\begin{tabular}{cccc}
\hline \hline PROTECTED AREAS & VILLAGE & NUMBER & $\begin{array}{c}\text { PERCENTAGE } \\
(\%)\end{array}$ \\
\hline RSPL & & 26 & 18 \\
& Bohog & 20 & 14 \\
LDNP & Cabacnitan & 22 & 15 \\
PNOC & Lake Danao & 22 & 15 \\
& Cambantug & 11 & 08 \\
& Cantilong & 15 & 10 \\
& Mahayahay & 15 & 10 \\
& Nueva Vista & 16 & 11 \\
\hline & Tongonan & $\mathbf{1 4 7}$ & $\mathbf{1 0 0}$ \\
\hline
\end{tabular}

LDNP is situated inside the. PNOC geothermal reservation. It covers an area of 2,193 hectares with a guitar-shaped 140-hectare lake: The park is proclaimed as a protected area pursuant to NIPAS Law by virtue of Proclamation no. 1155 dated February 3, 1996. It is placed under the management category of Natural Park primarily to protect and preserve its outstanding natural and scientific features of natural and international significance for scientific, educational, and recreational uses.

RSPL, on the other hand, is situated in the province of Bohol. It covers an area of 10,452 hectares of the interior portion of the province. It was designated as a national park on July 10, 1987 through proclamation No. 129. On April 23, 2000, it was proclaimed as a protected landscape through proclamation No. 287 and became part of the initial component of protected area network of NIPAS. Prior to its conversion as national park, RSPL has been the core component of Loboc Watershed Rehabilitation Project since the late 1950s.

Primary data were collected by interviewing 147 household heads using a semi-structured interview schedule. To gather more in-depth information, key informant interview was conducted. Secondary data were also obtained from 
different offices to reinforce primary data. Standard descriptive statistics were used to analyze the data gathered. Pearson product-moment correlation coefficient was employed to test the association between dependent (crop diversity) and independent variables (age, education, household size, labor force, farm size, farm income, off-farm and total income).

\section{Farming Systems}

\section{RESULTS AND DISCUSSION}

The dominant production system being practiced by the respondents inside the protected areas in the study villages have five broad categories, namely: traditional mosaic, low-input mosaic, low-input abaca-based intercrop, low-input staples and high-input vegetables. This classification was primarily based on the spatial arrangement and the type of major crops and the amount of inputs applied by the management.

\section{Traditional Mosaic}

This production system was characterized by the multi-storey mixed of perennial and annual crops most often for subsistence use only. This management system was used in relatively newly opened areas where the inherent soil fertility had warranted bountiful harvest even without the use of inorganic fertilizer. It was practiced in relatively sloping areas close to the forest margins. Most often, relatively flat areas are devoted to the production of staple crop particularly corn. Weeding is the only maintenance activity, which is performed only as the need arises. This cropping system is dominantly practiced by respondents in Cabacnitan where most farmers are also engaged in wet rice production outside the protected areas. 


\section{Low-input Mosaic}

This system is similar to the traditional mosaic except the use of fertilizer at low quantities and frequent weeding operations. The multi-storey species mixed of perennial and annual crops in sloping areas are usually enriched with fruit trees. Relatively flat portion of the farm is devoted to the production of corn and vegetables for both subsistence and cash.

This is the dominant production system in Nueva Vista and Tongonan, where most farmers have benefited from extension activities as manifested by the use of improved varieties of fruit trees and vegetables. Increase in the intensity of management is also evident due to the promotion of a rather sedentary production system.

\section{Low-input Abaca- based Intercrop}

This system is practiced in newly opened relatively big land claims. Normally, sloping areas, which constitute a big proportion of the farm, are devoted to abaca while relative flat areas in the farm are for staple and vegetables. Abaca is intercropped with coconut strategically spaced at some intervals so as not to compete with the abaca for light and moisture. The native tree species, anii (Erythrina fusca) is also planted as nurse crop and is preferred over coconut because of its significant contribution in moisture conservation.

Production of staples and vegetables is intensified with the use of inorganic fertilizer and improved varieties. Staples and vegetable production is an integral component of the overall production system because aside from subsistence, it is practically the source of cash during months when there is no harvest for abaca, the main crop. Abaca is harvested every six months hence, the contribution of short-term crops is very important. In some cases, farmers is shifting focus on short-term crops due to their attractive price in the market. More importantly, there is uncertainty in the stability of price of abaca during harvest time. This production system is being practiced by the respondents in Lake Danao and Mahayahay. 


\section{Low-input Staple}

Formerly, this was the dominant production system in relatively large flat areas suited to rice and corn cultivation. Areas where there was sufficient water for irrigation were devoted to wet-rice farming; relatively dry areas were utilized for corn production, and in few cases, for root crop production.

This was the dominant production system formerly practiced in Bohol. Sloping areas within the village were mostly spared from cultivation because of their very shallow topsoil, a characteristic associated with the karst environment. Consequently, limestone mogotes or hills appeared as protected regeneration, as if being deliberately protected, which was the source of the majority of the fuel requirement of the locality.

Use of inorganic fertilizer and improved varieties was evident in the site. Normally, farmers used 2 to 4 sacks of fertilizer per hectare for both rice and corn, which was considered low-input. But with the introduction of a contractgrowing scheme for yellow corn in the village, fertilizer use in the area was increasing significantly. A multi-commodity firm in Bohol had introduced to farmers the contract-growing scheme for corn to support the raw material requirement of its feed mill. The local municipal agriculture office facilitated the operation like processing of loar application and the conduct of land evaluation.

The ₹6,000-package loan that consisted of 20-kilogram hybrid corn seed and 7 sacks of fertilizer per hectare, shall be paid at harvest for 27,000 . The firm, as expected, sets the price at $\mathbb{Z} 3.20$ per kilo on a cob basis. Additional fee for transport of the produced is charged to the farmers depending on the distance of the farm to the town proper.

\section{High-input Vegetables}

This production system is associated with villages where areas for cultivation are limited and required cropping intensification being the only 
viable alternative to obtain enough family income the whole year round. This is characterized by the use of high value crops, which are generally high yielding and short lived but would require high input on fertilizer and pesticides.

This production system is dominant in Cambatug and Cantilong where most respondents are recent migrants with experience in plantation works in Mindanao. The generally flat terrain in the area and sufficient water for irrigation favored the practice of this production system. Crops are usually rotated in a year, but crops planted in a given time of the year may be uniform in the whole village and in neighboring areas with the same production system. This makes their production system seasonal in nature, which lead to the decline in price especially, if production is too high for the local market to absorb excess supply.

The problem in price decline is further aggravated by the involvement of financiers in Ormoc City in the price manipulation. Vegetable traders in Ormoc City would lend money without interest at all to these farmers for farm inputs such as fertilizer and pesticides on condition that they would get the produce at harvest. Unfortunately, these trader-financiers dictated the price to the disadvantage of the farmers who would end up with unpaid debts because of the unreasonably very low price tagged on their produce.

Farms are relatively small and are acquired from direct sell of rights or lease from the original claimants. Wealthier farmers used lands in adjacent areas outside the reservation to increase areas for cultivation. The limited land area for cultivation in this area coupled with the recent decline in soil fertility as a result of the high intensity cropping itself pose a great threat to the neighboring areas.

Many farmers are beginning to search for land inside the reservation for the same purpose. They had been motivated to look for arable lands inside the reservation because of the wrong notion that arable lands can be released 
to them even if they are inside the reservation. This notion was principally based on their first-hand experience of squatting first in the areas they presently occupy, which were eventually released to them. Although there has been no legal document issued to this effect, farmers perceived that they had already the legal rights over the land because of the mere recognition of the government of their existence in the area. There were instances that farmers were paid by PNOC for the improvement of their farms, which are affected by the construction of the geothermal pad and other structures.

\section{Farm Species Diversity}

Table 2 shows the mean number of agricultural crops planted by the respondents. The mean number for all villages was 2.89 , which ranged from 0 to 8 . This implies that most farms are not diversified and the highest number of crops grown in a single farm is 8 , which is in Nueva Vista. It could be worth noting that few respondents in Cantilong, Mahayahay and Tongonan are not raising agricultural crops at all. For Cantilong and Mahayahay, respondents are not raising agricultural crops simply because they do not have lands to till. For Tongonan, some respondents are inactive in farming due to old age.

Table 2. Mean number of agricultural crops raised by the respondents by study village

\begin{tabular}{clll}
\hline $\begin{array}{c}\text { PROTECED } \\
\text { AREAS }\end{array}$ & VILLAGE & MEAN & SD \\
\hline RSPL & Bohog & 2.65 & 0.85 \\
& Cabacnitan & 3.40 & 1.14 \\
LDNP & Lake Danao & 2.82 & 1.14 \\
PNOC & Cambantug & 2.88 & 1.32 \\
& Cantilong & 1.91 & 1.14 \\
& Mahayahay & 2.47 & 1.25 \\
& Nueva Vista & 3.60 & 2.10 \\
& Tongonan & 3.19 & 1.47 \\
\hline & Total & $\mathbf{2 . 8 9}$ & $\mathbf{1 . 3 5}$ \\
\hline
\end{tabular}


Agricultural crops grown by the respondents are classified into cash, vegetable, and root crops. Vegetables are not included under cash crops although some deliberately raised them for cash because most vegetables are for subsistence use only in the traditional rural society. Table 3 revealed that the widely grown crop for cash by 123 respondents is coconut (54\%), followed by corn $(43 \%)$, abaca $(39 \%)$ and rice $(33 \%)$. Only few respondents also raised cacao and cut flower. Most respondents in Cantilong and few in Cambantug raise cut flower. This could be due to the "radiation effect" of cut flower production, which started in the neighboring area of Milagro, which was popularly known for cutflower production. Coffee and peanut are the least grown crops among the respondents.

Table 3. Cash crops raised by the respondents*

\begin{tabular}{ccc}
\hline CROP & NUMBER & PERCENTAGE \\
\hline Coconut & 67 & 54 \\
Corn & 53 & 43 \\
Abaca & 48 & 39 \\
Rice & 41 & 33 \\
Cacao & 7 & 5 \\
Cut flower & 7 & 5 \\
Coffee & 3 & 2 \\
Peanut & 3 & 2 \\
\hline
\end{tabular}

*Multiple response, $n=123$

As regards vegetables, only 59 respondents reported that they are raising vegetables (Table 4). The most widely grown vegetable is bell pepper (44\%), followed by green onion $(39 \%)$ and tomato $(22 \%)$. It is important to note that most respondents who raised vegetables for cash come from the greater Tongonan area. Owing to their high market demand, bell pepper and tomato are the main cash crops in Cambantug and almost all respondents in this study village raise them. These two crops are widely grown because they would grow well even in farms that are repeatedly cropped the whole year round. Green onion is widely raised in greater Tongonan area because it requires low amount of fertilizer and less frequent weeding. 
Table 4. Vegetables raised by the respondents*

\begin{tabular}{ccc}
\hline VEGETABLE & NUMBER & PERCENTAGE \\
\hline Bell pepper & 26 & 44 \\
Green onion & 23 & 39 \\
Tomato & 13 & 22 \\
Eggplant & 10 & 17 \\
Cabbage & 6 & 10 \\
Sayote & 6 & 10 \\
Pechay & 5 & 8 \\
Squash & 5 & 8 \\
Ginger & 2 & 3 \\
Baguio beans & 1 & 2 \\
\hline
\end{tabular}

"Multiple response, $n=59$

Cabbage, which was once an important crop in Cambantug and Lake Danao, was no longer popularly grown in the area because of the restriction to open new areas for cultivation. Cabbage, according to respondents, thrived very well in newly opened areas because of the high fertility level of the soil. Ordinary farmers could not cope with the high input requirements if they grow cabbage in areas which are repeatedly cropped.

Few respondents (37) are growing root crops in their farms (Table 5). Most widely grown root crop is gabi $(70 \%)$, followed by camote $(51 \%)$ and cassava $(27 \%)$. The least grown root crop is ube. Only two respondents raised root crops in their farm despite the fact that most farms are situated in the uplands. Traditionally, root crops formed an integral part in the over-all subsistence production system in the uplands. This clearly indicates that most respondents are shifting orientation from the traditional management regime for subsistence to crop intensification for cash.

Table 5. Root crops raised by the respondent*.

\begin{tabular}{lcc}
\hline ROOT CROP & NUMBER & PERCENTAGE \\
\hline Gabi & 26 & 70 \\
Camote & 19 & 51 \\
Cassava & 10 & 27 \\
Ube & 2 & 5 \\
\hline
\end{tabular}

*Multiple response, $n=37$ 
Perennials also formed an integral part of the traditional upland farming systems. This component was evaluated based on the different fruit and forest trees planted by the respondents in their farm. Table 6 shows the mean number perennials raised by the respondents by study village. The total mean for fruit trees is 0.9 . . This means that in most cases, the respondents plant only 1 fruit tree species in their farm. The range was $0-8$, which means that some respondents are not even planting fruit trees at all, which is true to all respondents from Cantilong. The highest number of fruit tree species planted came from Tongonan, followed by Nueva Vista, Cantilong, and Lake Danao. Obviously, the result must be the effect of the extension work conducted by PNOC. As part of its extension program, PNOC had distributed seedlings of fruit trees to their beneficiaries.

Only 81 respondents are integrating fruit crops in their production system (Table 7). The most common grown fruit is banana (44\%), followed by nangka $(42 \%)$. These two crops are usually part of the traditional production system in the uplands and now become a common sight in almost every household in the rural areas of Leyte and Bohol. Most respondents in Cambantug and Lake Danao raise citrus.

Table 6. Mean number of perennial crops raised by the respondents by study village.

\begin{tabular}{clcccc}
\hline $\begin{array}{c}\text { PROTECTED } \\
\text { AREAS }\end{array}$ & VILLAGE & \multicolumn{2}{c}{ FRUIT TREES } & \multicolumn{2}{c}{ FOREST TREES } \\
\hline & & & & & \\
\hline RSPL & MEhol & 0.27 & 0.67 & MEAN & SD \\
& Cabacnitan & 0.70 & 0.73 & 1.50 & 0.71 \\
LDNP & Lake Danao & 1.18 & 1.30 & 0.50 & 0.82 \\
PNOC & Cambantug & 1.18 & 1.37 & 0 & 0.14 \\
& Cantilong & 0 & 0 & 0 & 0 \\
& Mahayahay & 0.27 & 1.03 & 0.20 & 0.77 \\
& Nueva Vista & 1.2 & 1.15 & 0.73 & 0.70 \\
& Tongonan & 3.0 & 2.80 & 0.44 & 0.96 \\
\hline & Total & 0.97 & 1.54 & $\mathbf{0 . 6 8}$ & 0.94 \\
\hline
\end{tabular}


Table 7. Fruit crops raised by the respondents*.

\begin{tabular}{lcc}
\hline FRUIT CROPS & NUMBER & PERCENTAGE \\
\hline Banana & 36 & 44 \\
Nangka & 34 & 42 \\
Citrus & 27 & 33 \\
Avocado & 19 & 23 \\
Rambutan & 12 & 14 \\
Mango & 9 & 11 \\
Lanzones & 7 & 9 \\
Tambis & 7 & 9 \\
Caimito & 6 & 7 \\
Santol & 5 & 6 \\
Pineapple & 4 & 5 \\
Marang & 4 & 5 \\
Durian & 3 & 4 \\
Kalamansi & 2 & 3 \\
Guava & 2 & 3 \\
Pomelo & 2 & 3 \\
Pili & 1 & 1 \\
\hline
\end{tabular}

"Multiple response, $n=81$

The mean number of tree species planted by the respondent in all study villages is 0.68 , which ranged from 0 to 4 . Bohog and Cabacnitan got 1.50 and 1.40 , respectively, while the rest got below 1 . The very low values indicate that most respondents are not conscious about integrating forest tree species in their farms. In fact, only 57 respondents are growing forest tree species in their farm with top 4 widely grown species being introduced or exotic species (Table 8). Very few respondents are domesticating native tree species.

Table 8. Forest trees raised by the respondents*.

\begin{tabular}{lcc}
\hline TREE SPECIES & NUMBER & PERCENTAGE \\
\hline Mahogany & 40 & 70 \\
Gmelina & 34 & 60 \\
Mangium & 11 & 19 \\
Ipil-ipil & 5 & 9 \\
Anii & 3 & 5 \\
Narra & 3 & 5 \\
Talisay & 1 & 2 \\
Molave & 1 & 2 \\
\hline
\end{tabular}

${ }^{*}$ Multiple response, $n=57$

80 
The relatively high value of crop for the villages in Bohol was a manifestation of the respondents' embracing tree planting in their farm but mainly with introduced species particularly mahogany and gmelina. During the early 1980s, beneficiaries of the ISF program in the study villages in Bohol were advised to plant mahogany and gmelina in the boundaries of their farms to serve as living monuments, which will be used to further substantiate their claim of their farms inside then Loboc Watershed Rehabilitation Project (LWRP). Seedlings were provided by LWRP as it was maintaining a nursery for the production of seedlings for distribution to beneficiaries until the late 1980s. Others deliberately established woodlot near their farms to have a steady supply of firewood and other wood materials for domestic use. A few others in Cabacnitan were even domesticating native tree species like tanguile (Shorea polysperma) in their farms in anticipation of the scarce supply of native timber species.

Mangium was widely grown among respondents in the greater Tongonan area. They availed of the seedlings distributed by PNOC. Surprisingiy, none from these study villages planted Dipterocarp species when in fact most of the respondents were involved in reforestation activities of PNOC using several species of Dipterocarps. This shows that farmers were only after of the direct benefit from tree planting in the form of wages. This lack of concern over planting native Dipterocarp species may be attributed to the fact that there are still abundant stocks of the species as perceived by farmers in the locality, which can be collected with less difficulty, coupled with the leniency demonstrated by PNOC when it comes to timber collection for domestic use among their beneficiaries.

Considering the total crops raised by the respondents in their farm, the mean was 4.45, which ranged from 0 to 13 (Table 9). Tongonan had the highest number while Cantilong had the lowest. Higher values were observed among study villages whose respondents are tilling lands inside protected areas while lower values were observed among respondents cultivating farms outside protected areas. The contribution of perennial crops in the means should not be undermined as they formed significant impact on the overall number of tree species grown in the said areas. Greater values must have come from the combination ci agricultural, fruit trees and forest trees. 
The most visible reasons for the difference in crop diversity could be tenure and exposure to extension programs. Higher crop diversity could be a compounded effect of tenure and extension programs. Respondents who were already secured regarding their claims of ownership of the land, generally embraced the technology package provided to them through extension programs particularly those involving the use of perennials. The reason for the low crop diversity could be associated more with the insecurity of tenure. Most respondents from Mahayahay and Cantilong are tenants, hence, they are only after the short-term benefits from their farm since they are not certain of the long-term benefits from growing perennial crops. In some cases, the landowners have to dictate what crops to be raised in their farms.

Table 9. Mean total number of crops raised by the respondents by study village.

\begin{tabular}{clcc}
\hline PROTECTED AREAS & VILLAGE & MEAN & SD \\
\hline RSPL & Bohol & 4.42 & 1.72 \\
& Cabacnitan & 5.50 & 1.64 \\
LDNP & Lake Danao & 4.50 & 2.69 \\
PNOC & Cambantug & 4.09 & 2.02 \\
& Cantilong & 1.91 & 1.14 \\
& Mahayahay & 2.93 & 2.71 \\
& Nueva Vista & 5.53 & 2.88 \\
& Tongonan & 6.62 & 4.22 \\
\hline & Total mean & $\mathbf{4 . 5 4}$ & $\mathbf{2 . 7 3}$ \\
\hline
\end{tabular}

\section{Correlates of Crop Diversity}

To determine the factors that are associated to farm-level species diversity, a correlation test using Pearson product-moment correlation coefficient was made with the total crop species as the dependent variable. Table 10 summarizes the relationship between selected variables and total crop species. Of the 9 variables tested, 7 were found to be significantly related to total crop species. 
Table 10. Correlation coefficient between total crop species and selected variables.

\begin{tabular}{lc}
\hline VARIABLES & $\begin{array}{c}\text { CORRELATION } \\
\text { COEFFICIENT }\end{array}$ \\
\hline Age & $0.231^{* *}$ \\
Education & 0.146 \\
Years in farming & $0.229^{* *}$ \\
Household size & $0.184^{*}$ \\
Farm size & $0.217^{*}$ \\
Farm income & 0.144 \\
Off-farm income & $0.209^{\star}$ \\
Total income & $0.284^{* *}$ \\
Livelihood project & $0.185^{*}$ \\
\hline "Significant at 5\% level & ${ }^{* *}$ Significant at 1\% level
\end{tabular}

Among the demographic variables, 3 showed significant relationship with total species count. These are age, years in farming, and household size. Age and years in farming of the respondents both showed positive relationship at $1 \%$ level of significance. This means that older respondents who are generally more experienced in farming would tend to grow more species of plants in their farms. The long experience in farming of the respondents may support the claim that planting different species of crops, including perennials like fruit trees and forest trees in their farm, is ecologically and economically beneficial.

Household size also showed positive relationship with total species count but at $5 \%$ level of significance. This means that household with bigger size would tend to grow more species of crops. This could probably be attributed to the number of household members who are available to perform farm activities, like planting and farm maintenance operations.

Among the economic variables tested, 3 showed positive relationship with the total species count. These are farm size, off-farm income, and total income. Farm size showed positive relationship at $5 \%$ level, which means that respondents with bigger farm size would be more inclined to grow different species of crops. Off-farm income and total income showed positive relationship at $5 \%$ and $1 \%$ levels of significance, respectively. Unfortunately, 
farm income did not show significant relationship. Number of years with livelihood support, the only institutional factor included in the analysis, also showed significant relationship at $5 \%$.

The results clearly revealed that crop diversification, particularly that involving perennials, may not provide immediate income to farmers. But it is interesting to note that even if they could not get direct short-term benefits from crop diversification, well-off respondents, who usually have bigger farms and bigger income from outside sources, would still likely to embrace crop diversification. Naturally, these respondents are not exclusively dependent on these crops because they had other sources of immediate income thus, they can wait for the crops to mature even for several years after planting.

There are good indications that farmers are willing to give up the traditional practice of cultivation if they could get substantial financial incentive in the form of income from other sources. This is In exchange of the income they could have derived from farming the same piece of land without going into diversification. Integrating tree crops would certainly reduce area for annual crops thereby, reducing the shot-term farm income. The result would further underscore the important role of integrating livelihood projects in any development programs concerning protected areas and other equally sensitive ecosystems. People may give up their unsustainable farming practices if they could have other sound alternatives for eking out a living.

\section{CONCLUSION AND RECOMMENDATION}

The most dominant resource use of communities inside the protected areas, which is agricultural cultivation, is shifting from subsistence to cash economy. Along this shift, farming system is also significantly changing from low to high intensity cropping, characterized by continuous cultivation and heavy application of inorganic fertilizer and pesticides. 
Farm level crop diversity was generally low. Perennial crops are integrated into the farming system but are limited only to few species of fruit trees and exotic forest trees. Farm level species diversity is positively related to age, number of years in farming, household size, farm size, off-farm income and number of years with livelihood projects.

Livelihood module must $b$, designed and implemented in order to lessen the dependence of the communities in the protective areas on these less sustainable farming practices at the same time prepare them towards attaining the ultimate goal of self-sufficiency. Livelihood projects, like enrichment planting of degraded ecosystems, must be provided initially for them to acquire capital for the expansion of their other livelihood endeavors. Market mechanisms must be considered an indispensable component of the package.

Support for institution building must be strengthened. To be able to participate in the activities in protected areas, inhabitants need basic education and literacy. They also need the specific skills necessary for employment and running small businesses. These skills can be acquired through short training courses and seminars.

\section{LITERATURE CITED}

DE BOER, W.F. and D.S. BAQUETE, 1998. Natural resource use, crop damage and attitude of rural people in the vicinity of the Maputo Elephant Reserve, Mozambique. Environmental Conservation 25(3):208-218.

DEPARTMENT OF ENVIRONMENT AND NATURAL RESOURCES, 1992. NIPAS Act (R.A. 7586) and Implementing Rules and Regulations (D.A.O. 25, s-1992). Quezon City: PAWB-DENR. 38p.

GLOWKA, L., F. BURHENNE-GUILMIN, H. SYNGE, J. McNEELY, and L. GUNDLING, 1994. A Guide to the Convention on Biological Diversity. IUCN Environmental Policy and Law Paper. 161p.

HEYWOOD, V.H. and R.T. WATSON, 1995. Global Biodiversity Assessment. Cambridge University Press, Cambridge. 1140p. 